\title{
Downregulation of Bim by brain-derived neurotrophic factor activation of TrkB protects neuroblastoma cells from paclitaxel but not etoposide or cisplatin-induced cell death
}

\author{
Z Li ${ }^{1,2}, \mathrm{~J} \mathrm{Zhang}^{2}, \mathrm{Z} \mathrm{Liu^{1 } , \mathrm { C } - \mathrm { W } \text { Woo }}{ }^{1,3}$ and CJ Thiele ${ }^{\star, 1}$
}

Chemoresistance and increased expression of TrkB and brain-derived neurotrophic factor (BDNF) are biomarkers of poor prognosis in tumors from patients with neuroblastoma (NB). Previously, we found BDNF activation of TrkB through PI3K/Akt protects NB from etoposide/cisplatin-induced cell death. In this study, the role of Bim, a proapoptotic protein, was investigated. Bim was involved in paclitaxel but not etoposide or cisplatin-induced cell death in NB cells. Pharmacological and genetic studies showed that BDNF-induced decreases in Bim were regulated by MAPK and not PI3K/Akt pathway. Both MAPK and PI3K pathways were involved in BDNF protection of NB cells from paclitaxel-induced cell death, while PI3K predominantly mediated BDNF protection of NB cells from etoposide or cisplatin-induced cell death. These data indicate that different chemotherapeutic drugs induce distinct death pathways and growth factors utilize different signal transduction pathways to modulate the effects of chemotherapy on cells.

Cell Death and Differentiation (2007) 14, 318-326. doi:10.1038/sj.cdd.4401983; published online 16 June 2006

Neuroblastoma (NB) is a pediatric solid tumor derived from neural crest precursor cells. ${ }^{1}$ Although NB tumors are initially sensitive to chemotherapy, they ultimately develop resistance. Understanding the signal transduction pathways that affect the sensitivity of NB cells to chemotherapy is important for developing more effective therapies. As cell lines and tumors from patients with a poor prognosis frequently express brain-derived neurotrophic factor (BDNF) and its tyrosine kinase receptor $\mathrm{TrkB},{ }^{2,3}$ we have studied the involvement of this signal transduction pathway in the sensitivity of cells to chemotherapy.

BDNF is a member of the neurotrophin family, which is important in the survival and development of the central nervous system. BDNF binds to the tyrosine kinase receptor TrkB and initiates multiple signaling cascades, including mitogen-activated protein kinase (MAPK) pathway, phosphatidyl-inositide 3-kinase (PI3K) pathway, and phospholipase C-gamma (PLC- $\gamma$ ) pathways. ${ }^{4,5}$ BDNF promotes survival of NB cells and protects them from chemotherapy. ${ }^{6,7}$ Our previous studies show that TrkB activation by BDNF protects NB cells from chemotherapy via activation of the PI3K pathway. ${ }^{8}$ More recently, we showed that Akt, a key target of PI3K, can functionally mimic BDNF to protect NB cells from etoposide and cisplatin-induced cell death. ${ }^{9}$

BDNF activation of TrkB stimulates PI3K and leads to phosphorylation and activation of Akt. ${ }^{10}$ Activated Akt phosphorylates and inhibits several proapoptotic proteins, such as Bad, caspase- 9 and the Forkhead transcription factors that include FKHRL1, FKHR and AFX, leading to cell survival. ${ }^{11-15}$ Although several growth factors (such as IGF-I, TGF, EPO, PDGF $)^{16-19}$ have been found to induce FKHRL1 phosphorylation via the Akt pathway, the role of Akt in BDNF regulation of FKHRL1 has not been explored. Forkhead transcription factor-induced cell death appears to be mediated by transcriptional regulation of a number of genes including Fas ligand (Fasl) ${ }^{15,20}$ and $\mathrm{Bim}$, a BH3 only domain protein that modulates the intrinsic mitochondrial death pathway. ${ }^{21}$ Alternative mRNA splicing generates three major isoforms of Bim: Extra-Long (BimEL), Long (BimL), and Short (BimS), with BimEL representing the predominant isoform in most tissues. ${ }^{22}$ FKHRL1-dependent increases in Bim mediate cell death upon cytokine withdrawal in a number of hematopoietic cell types ${ }^{23}$ and Bim functions as a tumor suppressor in solid tumors of epithelial origin and lymphomas. ${ }^{24,25}$ Akt regulates FKHRL1-dependent transcription of Bim in T-cells ${ }^{21}$ and neurons, ${ }^{26}$ while in other model systems regulation of Bim is independent of Akt and dependent on MAPK or mTOR activation. $^{27-34}$

In this study, we evaluated the regulation of Bim by BDNF/ TrkB pathway and its role in the sensitivity of NB cells to chemotherapy. Using TrkB-expressing NB cells and a gene silencing approach, we found that decreases in Bim by siRNAs targeted to Bim protected NB cells from paclitaxel but not etoposide or cisplatin-induced cell death. The BDNFinduced reduction of $\mathrm{Bim}$ was dependent on activation of MAPK and independent from activation of PI3K/Akt/FKHRL1

\footnotetext{
${ }^{1}$ Cell \& Molecular Biology Section, Pediatric Oncology Branch, Center for Cancer Research, National Cancer Institute, National Institutes of Health, Bethesda, MD, USA; ${ }^{2}$ The Second Affiliated Hospital of China Medical University, Shenyang, China and ${ }^{3}$ Department of Pediatrics, Korea University Anam Hospital, South Korea ${ }^{*}$ Corresponding author: CJ Thiele, Cell \& Molecular Biology Section, Pediatric Oncology Branch, National Cancer Institute, National Institutes of Health, 10 Center Drive MSC-1928, Bldg. 10/CRC 1-3940, Bethesda, MD 20892, USA. Tel: + 1301496 1543; Fax: + 1301451 7052; E-mail: ct47a@ nih.gov Keywords: neuroblastoma; Bim; BDNF; TrkB; paclitaxel; etoposide; cisplatin Abbreviations: BDNF, brain-derived neurotrophic factor; MAPK, mitogen-activated protein kinase; NB, neuroblastoma; PI3K, phosphatidyl-inositide 3-kinase Received 14.11.05; revised 02.5.06; accepted 03.5.06; Edited by M Piacentini; published online 16.6.06
} 
pathway. These studies indicated that different chemotherapeutic agents induced cell death via distinct mechanisms, and growth factors used distinct signal transduction pathways to attenuate the effects of cytotoxic agents.

\section{Results}

BDNF downregulates BimEL levels. Bim is reported to be a tumor suppressor ${ }^{24,25}$ and a downstream target of Akt/ FKHRL1. ${ }^{21,26}$ As our previous studies showed that PI3K/Akt pathway played an important role in BDNF/TrkB protection of NB cells from chemotherapy, ${ }^{8,9}$ we evaluated the role of the proapoptotic protein Bim in our model system. TB8 cells were treated with $100 \mathrm{ng} / \mathrm{ml} \mathrm{BDNF}$ for up to $6 \mathrm{~h}(0-6 \mathrm{~h})$ and BimEL, the phosphorylation of FKHRL1 (P-FKHRL1) and Akt (P-Akt, as a control of BDNF stimulation) and total FKHRL1 and Akt levels were assessed. As shown in Figure 1, BDNF activation of TrkB stimulated a reduction in BimEL levels in TB8 cells, and a rapid increase in phosphorylation of FKHRL1 and Akt. BimEL levels decreased within 5 min of BDNF stimulation, and remained depressed even after $6 \mathrm{~h}$. A 5-min stimulation of BDNF induced a five and six-fold increase in P-FKHRL1 and P-Akt, respectively. The increase of FKHRL1 and Akt phosphorylation remained detectable for at least $6 \mathrm{~h}$ while the levels of total FKHRL1 and Akt did not change. These data indicate that the BDNF/TrkB-induced decrease in BimEL levels was temporally related to the increases in Akt and FKHRL1 phosphorylation.

Silencing of BimEL by siRNA implicates Bim in paclitaxel but not etoposide or cisplatin-induced cell death in TB8 cells. To evaluate the role of BimEL in BDNF/ TrkB protection of TB8 cells from chemotherapy-induced cell death, we performed gene silencing experiments. Three different BimEL siRNA duplexes (no. 1, no. 2, no. 3) were transfected into TB8 cells and BimEL mRNA levels were examined $24 \mathrm{~h}$ post-transfection. The BimEL mRNA levels were decreased by more than $70 \%$ in cells transfected with BimEL siRNAs compared to cells transfected with control siRNA (Figure 2a). To evaluate if a decrease in BimEL levels by siRNA is involved in chemotherapy-induced cell death in TB8 cells, we transfected BimEL siRNA no. 2 , no. 3 or a control siRNA into TB8 cells. At $48 \mathrm{~h}$ after transfection, the

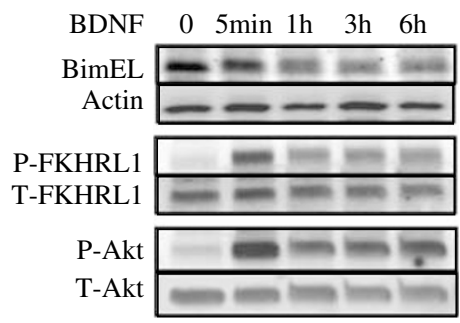

Figure 1 BDNF stimulation downregulated BimEL levels and induced phosphorylation of FKHRL1 in a time-dependent manner. TB8 cells were treated with $100 \mathrm{ng} / \mathrm{ml} \mathrm{BDNF}$, and then harvested at the indicated times $(5 \mathrm{~min}, 1,3,6 \mathrm{~h})$. Whole cell lysate were extracted and $30 \mu \mathrm{g}$ of total protein were analyzed for BimEL, P-FKHRL1 (Thr32), P-Akt (Ser 473), T-FKHRL1 and T-Akt by Western blotting. Actin was used as a loading control cells were analyzed either for BimEL expression (Figure 2b), or for their response to different concentrations of three chemotherapeutic drugs, paclitaxel $(5,10,20 \mu \mathrm{g} / \mathrm{ml})$, etoposide $(0.25,0.5,1 \mu \mathrm{g} / \mathrm{ml})$ and cisplatin $(0.5,1,3 \mu \mathrm{g} / \mathrm{ml})$ respectively (Figure $2 \mathrm{c}-\mathrm{e}$ ). Transfection of BimEL siRNA caused a $50 \%$ decrease in BimEL protein levels (Figure $2 b$ ) at the time cells were treated with paclitaxel, etoposide or cisplatin. In the paclitaxel-treated group, there was a $16 \%$ increase in the survival of the cells transfected with BimEL siRNA no. 2 or no. 3 which was statistically significant $(P<0.05)$ compared to the cells transfected with control siRNA (Figure 2c). However, in etoposide or cisplatin-treated groups, there was no difference in survival for TB8 cells transfected with BimEL siRNA no. 2 or no. 3 compared to cells transfected with control siRNA (Figure 2d, e). These results indicate that the decrease in BimEL levels using the BimEL siRNA altered the sensitivity of TB8 cells to paclitaxel but not etoposide or cisplatin.

BDNF protects NB cells from different types of chemotherapeutic drugs-induced cell death. To study the role of Bim in different types of chemotherapy-induced cell death in NB cells, we treated NB cells with paclitaxel, etoposide and cisplatin and evaluated changes in cell cycle distribution at multiple times after drug treatment. Figure $3 a$ shows that from 8 to $24 \mathrm{~h}$ of treatment with paclitaxel $(20 \mu \mathrm{g} / \mathrm{ml})$, there was an increase in the fraction of cells in the G2/M phase of the cell cycle, while by $48 \mathrm{~h}$ cells accumulated in the subG1 phase. These results show that after paclitaxel treatment TB8 cells arrested in the G2/M phase of the cell cycle prior to cell death. In contrast, when TB8 cells were treated with etoposide $(0.5 \mu \mathrm{g} / \mathrm{ml}$, Figure $3 \mathrm{~b})$ or cisplatin ( $3 \mu \mathrm{g} / \mathrm{ml}$, Figure $3 \mathrm{c})$, there was an increase in accumulation of cells in sub-G1 phase of the cell cycle within $16 \mathrm{~h}$ of treatment that continued at 24 and $48 \mathrm{~h}$. These results indicate that although TB8 cells were sensitive to paclitaxel and etoposide or cisplatin, the response of the cells to paclitaxel was distinct from their responses to etoposide or cisplatin. Our previous results showed that BDNF protected NB cells from etoposide and cisplatin-induced cell death. Etoposide and cisplatin are both DNA damaging drugs. Paclitaxel exerts its cytotoxic effect by binding microtubules and inhibiting their depolymerization into tubulin monomers. As paclitaxel was not analyzed in our previous studies, we tested whether BDNF would protect NB cells from paclitaxelinduced cell death. TB8 cells were pretreated with BDNF $(100 \mathrm{ng} / \mathrm{ml}, 1 \mathrm{~h})$ followed by $48 \mathrm{~h}$ treatment with different concentrations of paclitaxel $(5,10,20 \mu \mathrm{g} / \mathrm{ml})$. Depending on the paclitaxel dose, pretreatment with BDNF rescued up to $30 \%$ of the cells from drug induced-cell death and the effects of BDNF were statistically significant (Figure $3 d,{ }^{\star} P<0.05$, $\left.{ }^{\star *} P<0.01\right)$.

Silencing of BimEL mimics the ability of BDNF to protect TB8 cells from paclitaxel-induced cell death. As the cell cycle profiles of TB8 cells were distinct after treatment with paclitaxel and etoposide, we evaluated whether BDNF or silencing of BimEL would change the response of cells to paclitaxel and etoposide. We restricted these studies to etoposide since the response of the TB8 cells to etoposide 


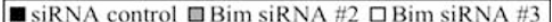

a

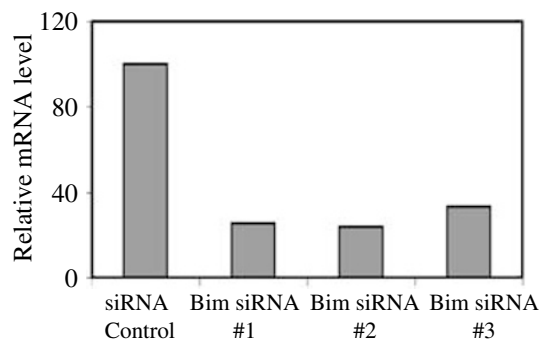

C

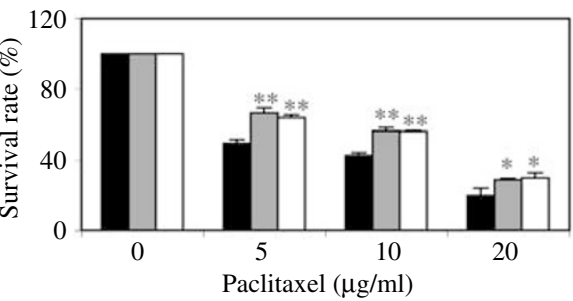

d

b Bim siRNA \#2 Control \#3
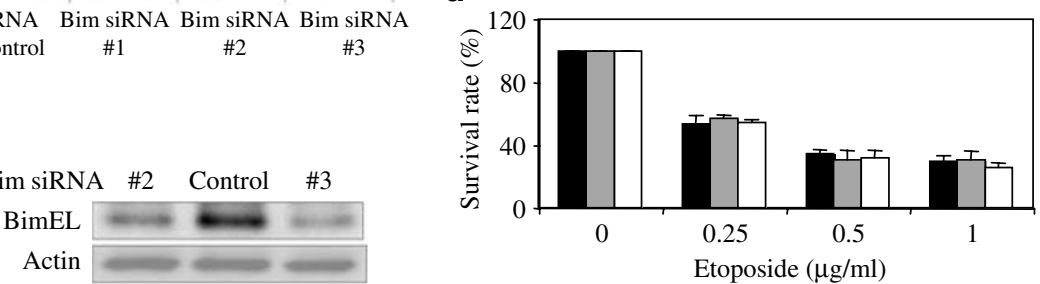

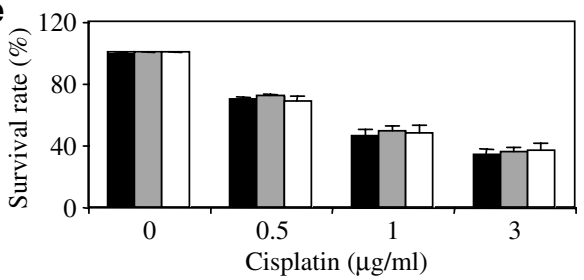

Figure 2 Silencing of BimEL by siRNA was involved in paclitaxel-induced cell death, but not etoposide or cisplatin-induced cell death in TB8 cells. $2 \mu \mathrm{g}$ BimEL siRNA no. 1 , no. 2, no. 3 or siRNA control were transfected into TB8 cells by nucleofector devices, respectively. At $24 \mathrm{~h}$ after transfection total RNA was prepared for RT-PCR. BimEL mRNA levels were detected and normalized by actin control (a). $2 \mu \mathrm{g} \mathrm{BimEL} \mathrm{siRNA} \mathrm{no.} \mathrm{2,} \mathrm{no.} 3$ or siRNA control were transfected into TB8 cells by nucleofector devices, respectively, $48 \mathrm{~h}$ after transfection, whole cell lysate were extracted and analyzed by Western blotting for BimEL and actin (b), and some TB8 cells were treated with paclitaxel (5, 10, $20 \mu \mathrm{g} / \mathrm{ml}, 48 \mathrm{~h})(\mathbf{c})$, etoposide $(0.25,0.5,1 \mu \mathrm{g} / \mathrm{ml}, 24 \mathrm{~h})(\mathbf{d})$ or cisplatin $(0.5,1,3 \mu \mathrm{g} / \mathrm{ml}, 24 \mathrm{~h})(\mathbf{e})$. MTS assay was used to detect cell survival. Survival rate in every condition was normalized to the no-chemotherapeutic drug control within every group. Bars, S.D. Significance was tested by ANOVA, Bonferroni was used as post-test. ${ }^{*} P<0.05$, ${ }^{\star \star} P<0.01$ versus siRNA control cells
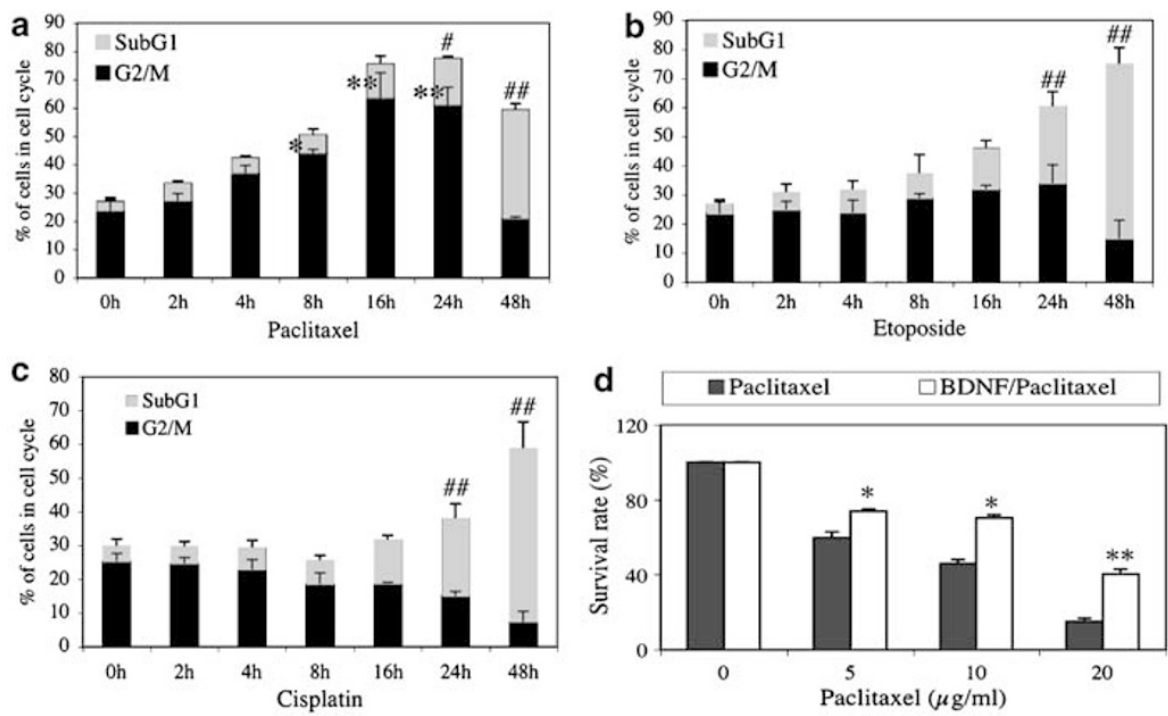

Figure 3 TB8 cells responsed differently to paclitaxel and etoposide or cisplatin treatment. TB8 cells were first treated with paclitaxel $(20 \mu \mathrm{g} / \mathrm{ml})(\mathbf{a})$, etoposide $(0.5 \mu \mathrm{g} / \mathrm{ml})$ (b) or cisplatin $(3 \mu \mathrm{g} / \mathrm{ml})$ (c) for the indicated time $(2,4,8,16,24,48 \mathrm{~h})$, then stained with $50 \mu \mathrm{g} / \mathrm{ml}$ propidium iodide and analyzed by flow cytometry. The percentages of cells in sub-G1 and G2/M phases of the cell cycle are analysed. Bars, S.D. Significance was tested by ANOVA followed by a Dunnett post-test to compare the drug-treated group at each time point versus the control group. ${ }^{\#} P<0.05,{ }^{\# \#} P<0.01$ for SubG1 analysis, ${ }^{*} P<0.05,{ }^{\star *} P<0.01$ for G2/M analysis. (d) TB8 cells were pretreated with BDNF $(100 \mathrm{ng} / \mathrm{ml})$ for $1 \mathrm{~h}$, and then treated with paclitaxel $(5,10,20 \mu \mathrm{g} / \mathrm{ml})$ for $48 \mathrm{~h}$. MTS assay was used to detect cell survival. Survival rate in every condition was normalized to the no-paclitaxel control within every group. Bars, S.D. ${ }^{*} P<0.05,{ }^{*} P<0.01$ versus paclitaxel-treated cells 
a

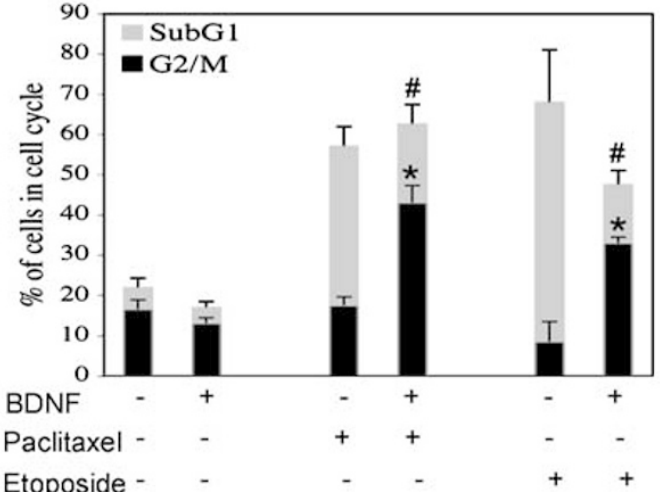

b

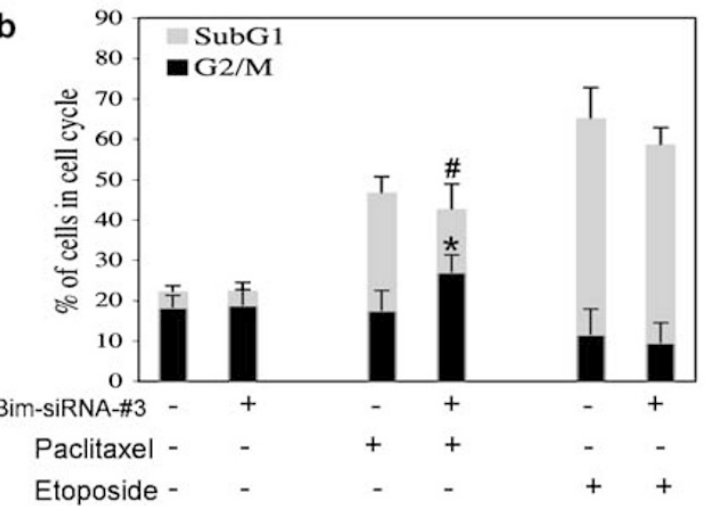

Figure 4 Silencing of BimEL by siRNA mimicked BDNF protection of TB8 cells from paclitaxel-induced cell death. TB8 cells were pretreated with BDNF $(100 \mathrm{ng} / \mathrm{ml})$ for $1 \mathrm{~h}(\mathrm{a})$, or transfected with $2 \mu \mathrm{g}$ Bim siRNA \#3 or siRNA control, and cultured for $48 \mathrm{~h}(\mathrm{~b})$, then treated with paclitaxel $(20 \mu \mathrm{g} / \mathrm{ml})$ or etoposide $(0.5 \mu \mathrm{g} / \mathrm{ml})$ for $48 \mathrm{~h}$. The cells were stained with $50 \mu \mathrm{g} / \mathrm{ml}$ propidium iodide and analyzed by flow cytometry. The percentages of cells in G2/M and sub-G1 phases of the cell cycle are analyzed. Bars, S.D. ${ }^{\#} P<0.05$ for SubG1, ${ }^{*} P<0.05$ for G2/M, versus paclitaxel- or etoposide-treated cells

and cisplatin were indistinguishable. We treated the TB8 cells with BDNF $(1 \mathrm{~h}, 100 \mathrm{ng} / \mathrm{ml})$ (Figure $4 \mathrm{a})$ or transfected with Bim siRNA no. 3 (Figure $4 \mathrm{~b}$ ), followed by treatment with paclitaxel $(20 \mu \mathrm{g} / \mathrm{ml})$ or etoposide $(0.5 \mu \mathrm{g} / \mathrm{ml})$ for $48 \mathrm{~h}$. Pretreatment with BDNF decreased the paclitaxel and etoposide-induced accumulation of cells in the sub-G1 fraction and increased the G2/M fraction of the cell cycle at $48 \mathrm{~h}$ (Figure 4a). Silencing of BimEL by Bim siRNA decreased the paclitaxel-induced accumulation of cells in the sub-G1 fraction and increased the G2/M fraction of the cell cycle at $48 \mathrm{~h}$. However silencing of BimEL levels had no effect on the cell cycle changes induced by etoposide treatment (Figure 4b). These results indicate that silencing of BimEL by Bim siRNA mimicked the ability of BDNF to protect TB8 cells from paclitaxel but not etoposide-induced cell death.

BDNF/TrkB-induced decreases in BimEL is mediated by MAPK but not PI3K pathway. Our previous finding that the PI3K/Akt pathway modulates cell sensitivity to etoposide/ cisplatin-induced cell death ${ }^{8,9}$ coupled with a lack of involvement of $\mathrm{Bim}$ in this process raises questions as to which signaling pathway mediated the BDNF/TrkB-induced a
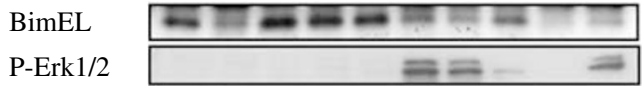

P-FKHRL1 $\square---\cdots$

P-Akt

Actin

BDNF

LY294002

PD98059

U73122

Rapamycin
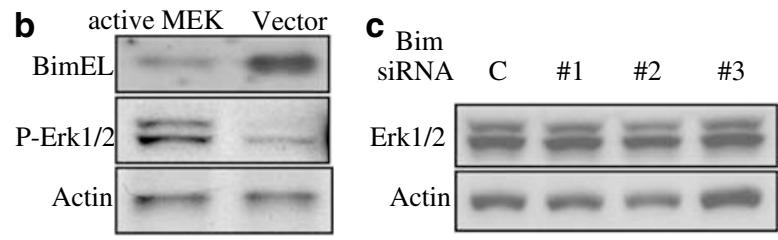

Figure 5 BDNF downregulated BimEL level via the MAPK pathway. (a) TB8 cells were cultured in RPMI 1640 containing $10 \%$ FBS for $24 \mathrm{~h}$, and then treated with different kinase inhibitors, PI3K pathway inhibitor-LY294002 $(20 \mu \mathrm{M})$, MAPK pathway inhibitor-PD98059 (40 $\mu \mathrm{M})$, PLC- $\gamma$ pathway inhibitor-U73122 $(20 \mathrm{nM})$, and mTOR pathway inhibitor-rapamycin $(100 \mu \mathrm{M})$ for $1 \mathrm{~h}$ followed by $100 \mathrm{ng} / \mathrm{ml}$ BDNF stimulation for $1 \mathrm{~h} .30 \mu \mathrm{g}$ of protein lysate was analyzed by Western blotting for BimEL, P-Erk1/2 (Thr 202/Tyr204), P-FKHRL1 (Thr32), P-Akt (Ser473). Actin was used as loading control. (b) $8 \mu \mathrm{g}$ GFP and either $12 \mu \mathrm{g}$ active MEK or $12 \mu \mathrm{g}$ empty vector were cotransfected into TB8 cells by electroporation. After $48 \mathrm{~h}$ transfection whole cell lysate were extracted and analyzed by Western blotting for BimEL, PErk1/2 and actin. (c) $2 \mu \mathrm{g}$ BimEL siRNA no. 1, no. 2, no. 3 or siRNA control were transfected into TB8 cells by nucleofector devices, respectively. At $48 \mathrm{~h}$ after transfection whole cell lysate were extracted and analyzed by Western blotting for Erk1/2 and actin

decreases in BimEL. TB8 cells were pretreated with different signal transduction pathway inhibitors (the PI3K inhibitor LY294002, the MAPK inhibitor PD98059, the PLC- $\gamma$ inhibitor U73122 and the mTOR inhibitor rapamycin), and then stimulated with BDNF. Except U73122, all the other inhibitors did not affect Bim levels (Figure 5a, lane 1, 3 and 4 versus control lane 5$)$. BDNF (100 $\mathrm{ng} / \mathrm{ml})$ caused a $40 \%$ decrease in BimEL levels (Figure $5 \mathrm{a}$, control-lane 5 versus BDNF-lane 6). Pretreatment of TB8 cells with the MAPK inhibitor PD98059 slightly reversed the BDNF-induced reduction in BimEL levels (Figure 5a, lane 8 versus lane 6). In contrast, the PI3K inhibitor LY294002 (Figure 5a, lane 7 versus lane 6), PLC- $\gamma$ inhibitor U73122 (Figure 5a, lane 9 versus lane 6 ), and the mTOR inhibitor rapamycin (Figure $5 a$, lane 10 versus lane 6) failed to significantly alter the BDNFinduced decrease in BimEL levels. In the same samples, we evaluated which signaling pathways mediated BDNFinduced phosphorylation of Akt and FKHRL1. Pretreatment of TB8 cells with LY294002 or U73122 blocked BDNFinduced phosphorylation of FKHRL1 and Akt. For Erk1/2, a target in the MAPK pathway (which we used to test the specificity of MAPK inhibitor), BDNF stimulation induced the phosphorylation of Erk1/2, which was blocked by pretreatment with PD98059 and U73122. Pretreatment with rapamycin did not affect BDNF-induced phosphorylation of FKHRL1, Akt or Erk1/2. 
We further examined the role of the MAPK pathway in BDNF/TrkB regulation of BimEL by transfecting a constitutively active MEK or a control empty vector into TB8 cells. Activation of MEK induced phosphorylation of its downstream target Erk1/2 in the cells transfected with the constitutively active MEK expression vector compared to empty vectortransfected cells (Figure $5 \mathrm{~b}$ ). At the same time, the BimEL levels decreased in constitutively active MEK-transfected cells compared to empty vector-transfected cells (Figure $5 b$ ). This indicated that activation of MAPK pathway was sufficient to reduce BimEL levels, and this result mimicked the regulation of BimEL by BDNF activation of TrkB. Meanwhile, when we silenced BimEL by BimEL siRNA, Erk1/2 levels did not change (Figure $5 \mathrm{c}$ ). This indicates that BimEL was downstream of Erk1/2 in the MAPK pathway. Using a pharmacologic and a genetic approach, these data indicate that the MAPK pathway mediated the BDNF/TrkB-induced decrease in BimEL levels.

BDNF protects NB cells from paclitaxel-induced cell death via both PI3K and MAPK pathways. To study the involvement of PI3K and MAPK pathways in the BDNF protection of NB cells from paclitaxel-induced cell death, we pretreated the cells with MAPK inhibitor PD98059 or PI3K inhibitor LY294002 $1 \mathrm{~h}$ before BDNF stimulation, and then treated with paclitaxel $(20 \mu \mathrm{g} / \mathrm{ml})$ for $48 \mathrm{~h}$. Pretreatment with BDNF increased the cell survival from 26 to $58 \%$ after paclitaxel treatment, so BDNF protected $32 \%$ of the cells from paclitaxel-induced cell death. Administration of PD98059 or LY294002 before BDNF stimulation blocked 13 or $20 \%$ of BDNF protection of the cells from paclitaxelinduced cell death, respectively (Figure 6a). To complement the pharmacologic approach, we used a genetic approach and found that the survival of the cells transfected with constitutively active MEK was $14 \%$ higher than that of the cells transfected with empty vector (Figure 6b). These results indicate that both the PI3K and MAPK pathways were involved in the BDNF protection of TB8 cells from paclitaxelinduced cell death. To investigate in more detail if MAPK pathway was involved in BDNF protection on TB8 cells from etoposide and cisplatin-induced cell death, we either pretreated the cells with MAPK inhibitor PD98059 $(40 \mu \mathrm{M}$, $1 \mathrm{~h})$ before BDNF stimulation, or transfected the cells with constitutively active MEK or empty vector before etoposide
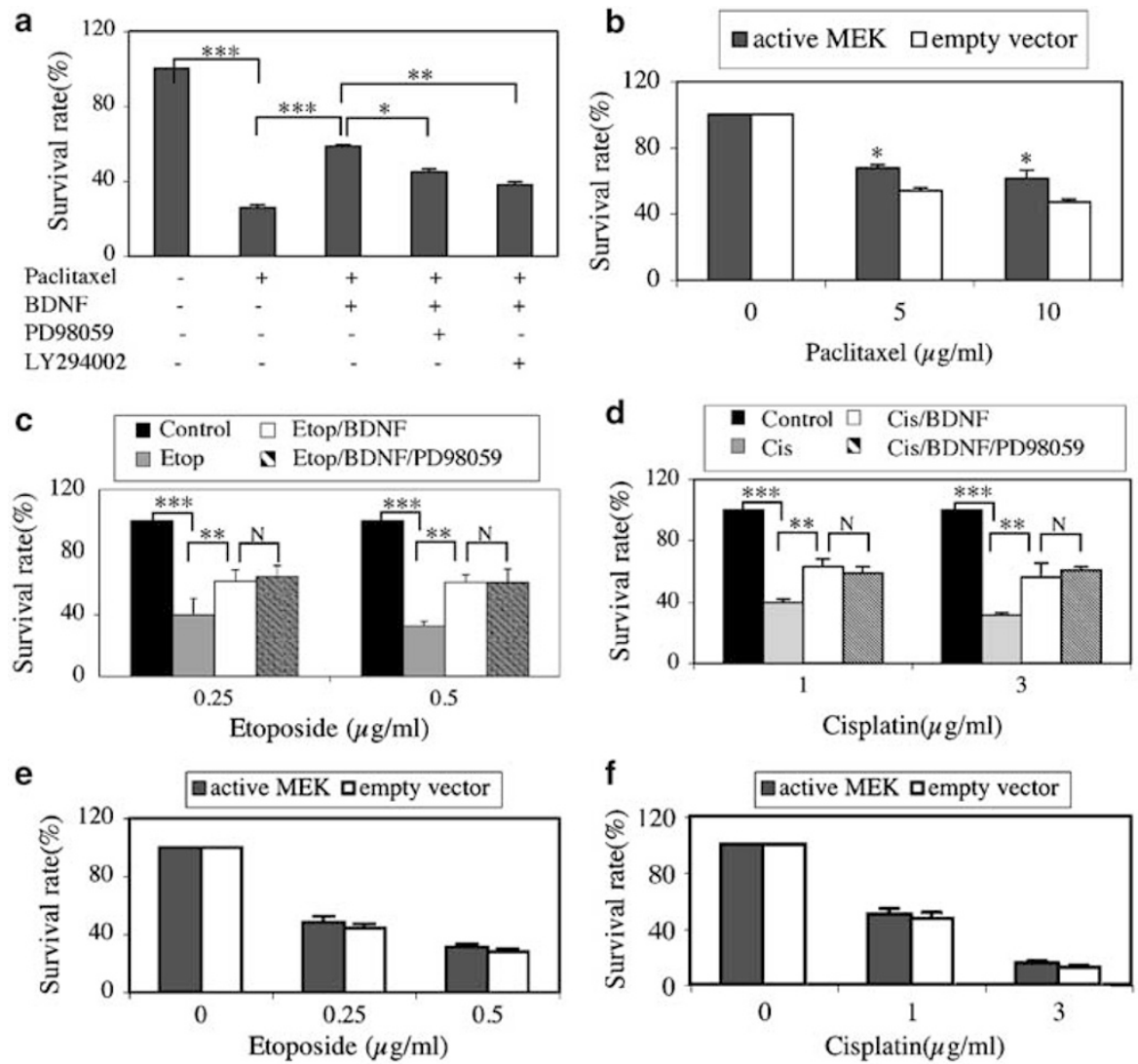

Figure 6 Both MAPK and PI3K pathways were involved in BDNF protection of NB cells from paclitaxel-induced cell death. After the indicated treatment of TB8 cells, MTS assay was used to detect cell survival. Survival rate in every condition was normalized to the no-chemotherapeutic drug control within every group. Bars, S.D. (a) TB8 cells were pretreated with MAPK inhibitor PD98059 $(40 \mu \mathrm{M}, 1 \mathrm{~h})$ or PI3K inhibitor LY294002 $(20 \mu \mathrm{M}, 1 \mathrm{~h})$ before BDNF stimulation $(100 \mathrm{ng} / \mathrm{ml}, 1 \mathrm{~h})$, and then treated with paclitaxel $(20 \mu \mathrm{g} / \mathrm{ml}, 48 \mathrm{~h})$. Significance was tested by ANOVA, Bonferroni was used as post test. ${ }^{\star} P<0.05,{ }^{\star \star} P<0.01,{ }^{\star \star \star} P<0.001$. (b, e and f) TB8 cells were co-transfected with $8 \mu \mathrm{g}$ GFP and either $12 \mu \mathrm{g}$ active MEK or $12 \mu \mathrm{g}$ empty vector and cultured for $48 \mathrm{~h}$, then treated with paclitaxel $(5,10 \mu \mathrm{g} / \mathrm{ml}, 48 \mathrm{~h})(\mathbf{b})$, etoposide $(0.25,0.5 \mu \mathrm{g} / \mathrm{ml}, 24 \mathrm{~h})(\mathbf{e})$ or cisplatin $(1,3 \mu \mathrm{g} / \mathrm{ml}, 24 \mathrm{~h})$ (f) respectively. ${ }^{*} P<0.05$, versus empty vector transfected cells. (c and d) TB8 cells were pretreated with PD98059 (40 $\mu$ M, $1 \mathrm{~h}$ ) followed by BDNF stimulation $(100 \mathrm{ng} / \mathrm{ml}, 1 \mathrm{~h})$, and then treated with etoposide $(0.25,0.5 \mu \mathrm{g} / \mathrm{ml})(\mathbf{c})$ or cisplatin $(1,3 \mu \mathrm{g} / \mathrm{ml})(\mathrm{d})$ for $24 \mathrm{~h}$, respectively. Significance was tested by ANOVA, Bonferroni was used as post-test. ${ }^{\star \star} P<0.01,{ }^{\star \star *} P<0.001$, N: no statistical difference 
(0.25, $0.5 \mu \mathrm{g} / \mathrm{ml})$ or cisplatin $(1,3 \mu \mathrm{g} / \mathrm{ml})$ treatment. Pretreatment of the cells with PD98059 did not affect the ability of BDNF to protect TB8 cells from etoposide or cisplatin-induced cell death (Figure 6c, d). Moreover, transfection of constitutively active MEK into TB8 cells did not alter the survival of the cells after etoposide or cisplatin treatment (Figure 6e, f). These data indicate that the MAPK pathway was not involved in BDNF protection of NB cells from etoposide or cisplatin-induced cell death.

To extend our studies, we established another TrkBexpressing cell line by transfecting pBPSTR1-TrkB ${ }^{8}$ to the $\mathrm{N}$-myc amplified NGP NB cell line and isolating a puromycin resistant clone (NGP-TrkB). Like the TB8 cells, ${ }^{8}$ when cells were cultured in the absence of tetracycline (TET) there was an increase in TrkB levels compared to cells cultured in the presence of TET (Figure 7a). BDNF treatment of NGP-TrkB cells caused a $50 \%$ decrease in BimEL levels. Pretreatment with the MAPK inhibitor PD98059, but not the PI3K inhibitor LY294002, prior to BDNF stimulation, blocked the decrease of BimEL (Figure 7b). BDNF-induced phosphorylation of Akt

a

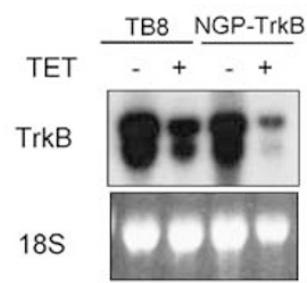

c
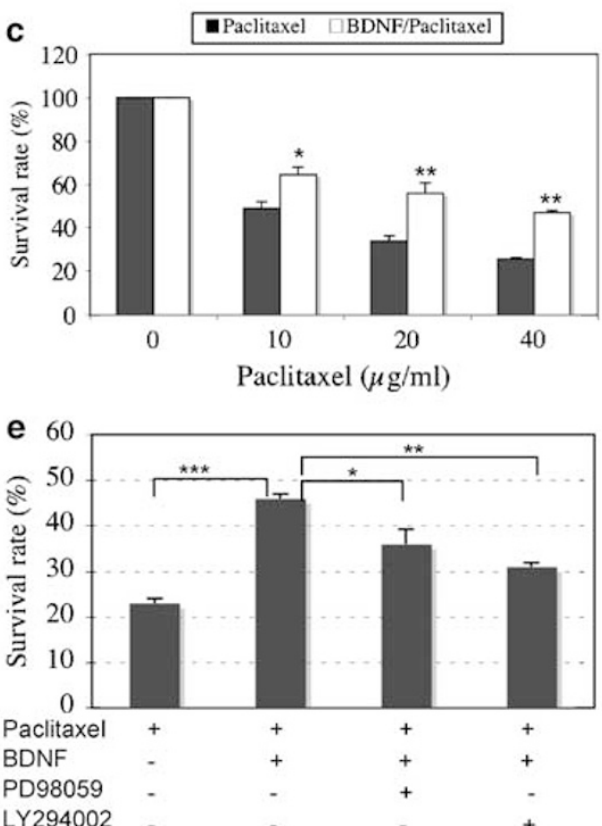

was blocked by LY294002, but not by PD98059 (Figure 7b). NGP-TrkB cells were sensitive to paclitaxel and etoposide treatment and pretreatment with BDNF resulted in a significant increase in the survival of cells from paclitaxel or etoposide treatment $\left({ }^{\star} P<0.05,{ }^{\star *} P<0.01\right)$ (Figure 7c, d). Consistent with our studies in TB8 cells, BDNF treatment protected 23 or $29 \%$ of NGP-TrkB cells from paclitaxel or etoposide-induced cell death respectively. Pretreatment with PD98059 before BDNF stimulation blocked $11 \%$ of BDNF protection of cells in paclitaxel-treated cells (Figure 7e), but had no effect in etoposide-treated cells (Figure 7f). Pretreatment with LY294002 before BDNF stimulation blocked 16 or $19 \%$ of BDNF protection of cells from paclitaxel or etoposideinduced cell death (Figure $7 \mathrm{e}, \mathrm{f}$ ) respectively.

\section{Discussion}

Our results showed that silencing of BimEL by siRNA protected TB8 cells from paclitaxel-induced cell death, but not etoposide or cisplatin-induced cell death. This indicates for
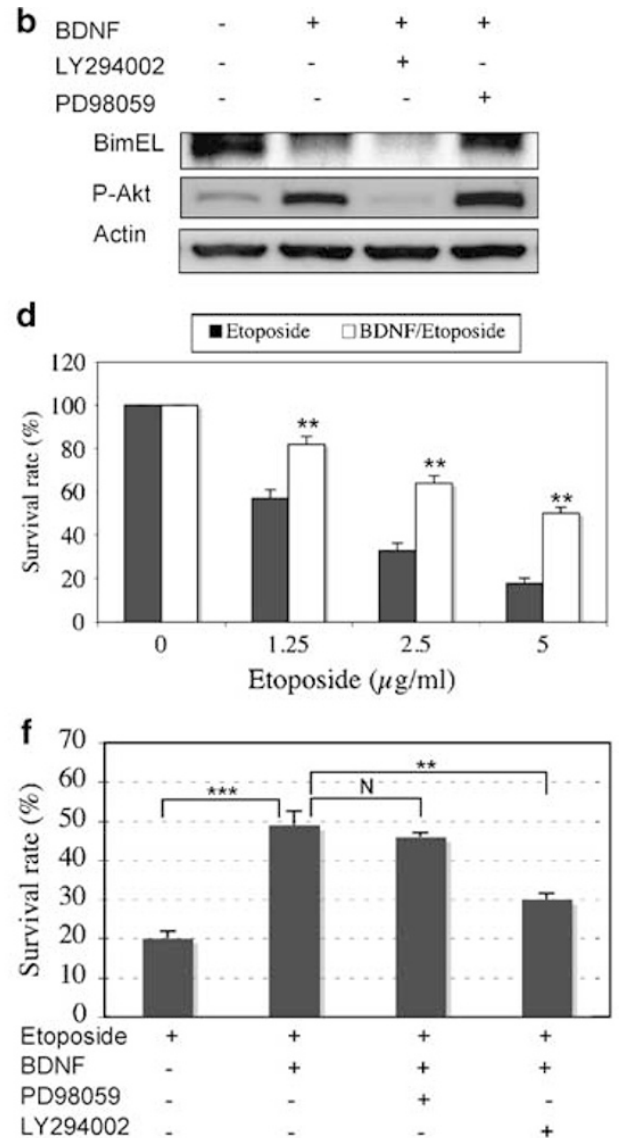

Figure 7 MAPK pathway was involved in BDNF protection from paclitaxel-induced cell death in NGP-TrkB cells. (a) TrkB mRNA expression in TB8 and NGP-TrkB cells was assessed by Northern Blot analysis as described in 'Materials and methods'. 18 s RNA served as a loading control. (b) NGP-TrkB cells were treated with PD98059 (40 $\mu$ M) or LY294002 $(20 \mu \mathrm{M})$ for $1 \mathrm{~h}$ followed by $100 \mathrm{ng} / \mathrm{ml} \mathrm{BDNF}$ stimulation for $30 \mathrm{~min}$. Thirty $\mu \mathrm{g}$ of protein lysate were analyzed by Western blotting for BimEL, P-Akt(Ser473) and action. (c and d) NGP-TrkB cells were pretreated with BDNF $(100 \mathrm{ng} / \mathrm{ml})$ for $1 \mathrm{~h}$, and then treated with paclitaxel $(10,20,40 \mu \mathrm{g} / \mathrm{ml})$ or etoposide $(1.25,2.5,5 \mu \mathrm{g} / \mathrm{ml})$ for $48 \mathrm{~h}$. MTS assay was used to detect cell survival. Survival rate in every condition was normalized to the no-chemodrug control within every group. Bars, S.D. ${ }^{*} P<0.05,{ }^{\star *} P<0.01$ versus paclitaxel or etoposide-treated cells. (e ,f) NGP-TrkB cells were pretreated with PD98059 $(40 \mu \mathrm{M}, 1 \mathrm{~h})$ or LY294002 $(20 \mu \mathrm{M}, 1 \mathrm{~h})$ before BDNF stimulation $(100 \mathrm{ng} / \mathrm{ml}$, $1 \mathrm{~h})$, and then treated with paclitaxel $(40 \mu \mathrm{g} / \mathrm{ml})$ or etoposide $(5 \mu \mathrm{g} / \mathrm{ml})$ for $48 \mathrm{~h}$. MTS assay was used to detect the cell survival. Survival rate in every condition was normalized to the no-chemodrug control within every group. Bars, S.D. Significance was tested by ANOVA, Bonferroni was used as post-test. ${ }^{*} P<0.05,{ }^{* *} P<0.01,{ }^{* * *} P<0.001, N$ : no statistical difference 
the first time that the role of BimEL in the BDNF/TrkB protection of NB cells is drug-dependent. Etoposide and cisplatin are DNA damaging drugs; etoposide inhibits DNA topoisomerase II, thereby inhibiting DNA synthesis, while cisplatin binds to DNA and interferes with its repair mechanism. Both interventions eventually lead to cell death. Conversely, paclitaxel stabilizes microtubules, activating the spindle assembly checkpoint and mitotic arrest. ${ }^{35}$ Our cell cycle analysis showed that TB8 cells arrested in the G2/M phase prior to cell death when treated with paclitaxel. This is very similar to the cell cycle changes noted in breast cancer cells after paclitaxel treatment. ${ }^{36}$ Considering the known proapoptotic mechanism of Bim, this may be why Bim plays a role in paclitaxel-induced cell death. Bim is thought to induce cell death by binding to LC8 cytoplasmic dynein light chain where it is sequestered with the microtubule-associated dynein motor complex in healthy cells. ${ }^{37}$ Certain apoptotic stimuli disrupt the interaction between LC8 and the dynein motor complex freeing Bim to translocate together with LC8 to Bcl-2 and neutralize its anti-apoptotic activity. ${ }^{37}$ In our present study, when the Bim levels were reduced by Bim siRNA, the accumulation of cells in sub-G1 phase induced by paclitaxel treatment decreased. Similarly, transfection of Bim siRNA into MCF-7 breast cancer cells inhibited apoptosis induced by paclitaxel treatment. ${ }^{36}$ However, silencing of BimEL had no effect on the accumulation of TB8 cells in the sub-G1 portion of the cell cycle after treatment with etoposide or cisplatin. This indicates that Bim levels do not play a role in modulating etoposide or cisplatin-induced cell death in NB cells and this finding may also be relevant to other tumor types.

Initially, we had hypothesized that Bim would be an important mediator of the survival of NB cells after BDNF activation of TrkB via the PI3K/Akt pathway. However, our pharmacologic and genetic experiments indicated that the BDNF-induced reduction in Bim levels was mediated by activation of MAPK, not the PI3K/Akt pathway. As a BH3-only proapoptotic protein, Bim is expressed in hematopoietic, epithelial, neuronal and germ cells. ${ }^{38}$ It is predominantly regulated by FKHRL1, ${ }^{21,23-26}$ and the molecular mechanism associated with FKHRL1 regulation has largely been characterized in response to growth factor signaling via the evolutionarily conserved PI3K/Akt survival signaling pathway. ${ }^{16-19,39}$ Using pharmacological inhibitors we found that FKHRL1 was regulated by the PI3K pathway. This is consistent with what has been reported for BDNF activation of endogenous TrkB receptors in SY5Y NB cells by Zhu et al. ${ }^{40}$ Moreover, a PI3K inhibitor did not block the BDNFinduced reduction of $\mathrm{Bim}$. This indicates that in our cell model system, the downregulation of Bim by BDNF is independent of PI3K, Akt and FKHRL1. Although Bim is reported to be regulated mainly via the $\mathrm{PI} / \mathrm{K} / \mathrm{Akt} / \mathrm{FKHRL} 1$ pathway in a number of cell lines, ${ }^{21,23-26}$ there is increasing evidence that Bim regulation is complex and regulated by multiple growth factor signaling pathways which are cell-type specific. ${ }^{26-34}$ In our study, transfection of constitutively active MEK into NB cells decreased Bim levels and a pharmacological inhibitor of the MAPK pathway blocked the BDNF-induced reduction in Bim levels. This indicates that Bim is regulated by the MAPK pathway upon BDNF activation of TrkB in NB cells. The MAPK pathway is also important in the NGF inactivation of BimEL in
PC12 cells. ${ }^{41}$ In that study, BimEl is inactivated via an early phopshorylation event while an NGF induced decrease in BimEL levels occurs over several days. In our studies, BDNF/ TrkB stimulates a decrease in BimEL levels that occurs within $1 \mathrm{~h}$ of treatment. The difference in regulation of BimEL may be due to differences in the cell type, the activation of different Trk signaling paths by their ligands. Recent evidence indicates that activation of TrkA leads to distinct changes compared to activation of TrkB in neuroblastoma cells. ${ }^{42}$

In identifying the signaling pathways that mediate the BDNF/TrkB protection of NB cells from paclitaxel, etoposide or cisplatin, we found that both the PI3K and MAPK pathways protected NB cells from paclitaxel-induced cell death, while only the PI3K pathway protected cells from etoposide and cisplatin-induced cell death. The involvement of MAPK pathway in paclitaxel-induced cell death is consistent with our findings that Bim was regulated by BDNF via the MAPK pathway and Bim only altered the response of NB cells to paclitaxel-induced cell death signals. Our finding is consistent with the report by Tan et al. ${ }^{24}$ in which MAPK pathway confers resistance to paclitaxel that is dependent on functional inactivation of Bim. This indicates that the efficacy of paclitaxel therapy may be dependent on the activation status of the MAPK pathway and Bim levels in certain tumors. ${ }^{24,35,36,43}$ The involvement of PI3K pathway in both etoposide/cisplatin- and paclitaxel-induced cell death indicated that the PI3K pathway still plays an important role in the BDNF protection of NB cells from chemotherapy. So our current studies are aimed at identifying the downstream targets of the PI3K pathways that mediate the BDNF protection of NB from chemotherapy. Such studies are important as more and more inhibitors of signal transduction pathways are being combined with different chemotherapeutic regimens. ${ }^{44}$ The more restricted or specific the targets are, the more effective and less cytotoxic the treatment may be. In the future we will also assess the effects of different inhibitors in our in vivo NB models.

To summarize, our data demonstrate that although BDNF/ TrkB can protect NB cells from cell death induced by different chemotherapeutic drugs, the mechanism by which BDNF activation of TrkB protects cells depends on the mechanism of cell death induced by the chemotherapeutic drugs. This study indicates that to more effectively utilize small molecule inhibitors of survival signaling pathways with traditional chemotherapy will require a detailed blueprint of the chemotherapy-associated apoptotic pathways and survival pathways utilized by different cell types. In the clinic these data will lead to better understanding of how to combine chemotherapeutic drugs with different signal transduction pathway inhibitors, to improve the efficacy of therapeutic regimens.

\section{Materials and Methods}

Cells and cell culture. Stable TrkB expressing cell line-TB8 cells ${ }^{45}$ and NGP. TrkB cells were cultured in RPMI 1640 (Mediatech Inc., Herndon, VA, USA) containing $10 \%$ fetal bovine serum (FBS), $2 \mathrm{mM}$ glutamine, and antibiotics at $37^{\circ} \mathrm{C}$ in $5 \% \mathrm{CO}_{2}$ incubator as described previously. ${ }^{8}$ To maintain selection pressure the TB8 and NGP-TrkB cells were cultured in puromycin $(0.5 \mu \mathrm{g} / \mathrm{ml})$ (Sigma-Akdrich Inc., Steinhein, Germany).

DNA Vector Constructions. Constitutively active MEK and empty vector were provided by Dr. Natalie G Ahn. ${ }^{46}$ 
Reagents. Recombinant human BDNF was obtained from PeproTech Inc. (Rocky Hill, NJ, USA). LY294002, PD98059, U73122 and Rapamycin were purchased from Cell Signaling Technology (Beverly, MA, USA). Anti-phosphoFKHRL1 (Thr32), anti-Akt, anti-phopspho-Akt (Ser473), anti-phospho-Erk1/2 (Thr202/Tyr204) and anti-Erk1/2 were obtained from Cell Signaling Technology, while anti-FKHRL1 (Upstate Biotechnology, Lake Placid, NY, USA), anti-Bim (Santa Cruz Biotechnology, Santa Cruz, CA, USA), and actin (Abcam Ltd Cambridge, UK) were obtained from indicated sources. Paclitaxel, etoposide and cisplatin were purchased from Sigma (St Louis, MO, USA).

Protein analysis. Proteins were detected by Western blotting with indicated antibodies as described previously. ${ }^{8}$ Briefly, protein lysates $(30 \mu \mathrm{g})$ were analyzed by SDS-PAGE and transferred to nitrocellulose. The indicated primary antibodies were diluted according to manufactures's recommendations and detected with horseradish peroxidase-conjugated goat anti-rabbit or anti-mouse IgG $(1: 2000$ dilution).

Transfections. TB8 $\left(8 \times 10^{6}\right)$ cells in $400 \mu$ l media were co-transfected with green fluorescent protein (GFP, $8 \mu \mathrm{g}$ ) and either constitutively active MEK $(12 \mu \mathrm{g})$ or empty vector control $(12 \mu \mathrm{g})$ by electroporation at $250 \mathrm{mF}$. Bim siRNA and siRNA control (Dharmacon Inc., Lafavette, CO, USA) were transfected into TB8 $\left(2 \times 10^{6}\right)$ cells by Nucleofector device from Amaxa Biosystems (Allemangne, Germany), using cell line nucleofector ${ }^{\mathrm{TM}}$ kit $\mathrm{V}$ and program $\mathrm{A}-023$.

Real-time quantitative PCR. Total RNA was isolated using a Qiagen Extraction procedure. ${ }^{8}$ Equal amounts of total RNA $(2 \mu \mathrm{g})$ were reverse-transcribed using the Superscript First-Strand Synthesis System for RT-PCR (Invitrogen), and the resulting first strand $C D N A$ was diluted and used as template in the real-time quantitative-PCR analysis. All measurements were performed in triplicate. Actin served as internal control and was used to normalize the variances in input cDNA. The following gene-specific primer pair was designed using the $A B I$ Primer Express software: Bim-sense 5'-GCCCAAGAGTTGCGGCGTA-3'; Bim-antisense 5'-CACA CCAGGCGGACAATGTAA- $3^{\prime}$. The specificity of each primer was determined using NCBI BLAST module. Detection of Bim expression was performed with SYBR Green (Applied Biosystems) and an ABI PRISM 7700 Sequence Detection System (Applied Biosystems), using the relative standard curve method.

Gene silencing with small interfering RNAs. We designed and purchased three small interfering RNA (siRNA) oligonucleotides from Dharmacon Research Inc. (Lafayette, CO, USA). TB8 cells were cultured $48 \mathrm{~h}$ before transfection. Oligonucleotides $(2 \mu \mathrm{g})$ were transfected into TB8 cells using an Amaxa neucleofector device, program A-023 and cell line Nucleofector $^{\mathrm{TM}} \mathrm{kit} \mathrm{V}$ from Amaxa Biosystems. At $24 \mathrm{~h}$ after transfection, cells were harvested for extraction of RNA. At $48 \mathrm{~h}$ after transfection cells were collected for Western Blot, or treated with chemotherapeutic drugs. The oligonucleotides were as follows: no. 1 Bim sense 5'-UUACGACUGUUACGUUACA(dTdT)-3'; no. 1 Bim antisense 5'-UGUAACGUA ACAGUCGUAA(dTdT)-3'. no. 2 Bim sense $5^{\prime}$-GCAACCUUCUGAUGUAAGU (dTdT)-3'; no. 2 Bim antisense 5'-ACUUACAUVAGAAGGUUGC(dTdT)-3'. no. 3 Bim sense $5^{\prime}$-GACAGAGCCACAAGGUAAU(dTdT)-3'; no. 3 Bim antisense 5'-AUUACCUUGUGGCUCUGUC(dTdT)-3'.

Treatments. To study the inhibitory effect of LY294002, PD98059, U73122, and Rapamycin on cell signaling, NB cells were plated into six-well plates in RPMI 1640 containing $10 \% \mathrm{FBS}$ and incubated for $24 \mathrm{~h}$. Cells were pretreated with different inhibitors for $1 \mathrm{~h}$, then stimulated with $100 \mathrm{ng} / \mathrm{ml}$ BDNF or media control for $1 \mathrm{~h}$. To study the cell survival after treatment with chemotherapeutic drugs, NB cells were either pretreated with LY294002 or PD98059 followed by BDNF, or pretreated with only BDNF, or cultured for $48 \mathrm{~h}$ after transfection, and then treated with indicated chemotherapeutic drugs (paclitaxel, etoposide and cisplatin) for 24 or $48 \mathrm{~h}$. MTS assay was used to detect the cell survival.

Cell survival analysis. The 3-(4,5-dimethylthiazol-2-yl)-5-(3-carboxymethoxyphenyl)-2-(4-sulfophenyl)-2H-tetrazolium, inner salt assay (MTS assay) was performed according to the manufacturer's specification. The percentage of cell survival (survival rate) was calculated by dividing the absorbance value of the treated samples by the absorbance value of the untreated control within every group. All experiments were repeated two to three times.
Cell cycle analysis. Cell cycle analysis was performed using propidium iodide staining. TB8 cells were harvested, washed with PBS twice and stained with $50 \mu \mathrm{g} / \mathrm{ml}$ propidium iodide containing $5 \mu \mathrm{g} / \mathrm{ml}$ DNAse-free RNase A for $1 \mathrm{~h}$ at room temperature, and analyzed by flow cytometry with a FACScan and Cell Quest software (BD Biosciences).

Northern blot analysis. RNA isolation and hybridization were performed as described previously. ${ }^{8}$ Total RNA (12 $\mu \mathrm{g}$ ) harvested from TB8 and NGP-TrkB cells cultured in the absence and presence of tetracycline $(1 \mu \mathrm{g} / \mathrm{ml})$ for 3 days were electrophoresed in $1 \%$ agarose- $6 \%$ formaldehyde gels. Gels were stained with $2 \mu \mathrm{g} / \mathrm{ml}$ ethidium bromide and $18 \mathrm{~S}$ RNA served as a loading control. Hybridization was performed with ${ }^{32} \mathrm{P}$-labed insert DNA isolated from a plasmid containing rat-TrkB.

Statistics. Significance was tested by ANOVA using GraphPad InStat software for Macintosh. Bonferroni or Dunnett were used as post-test. Two group comparisons were performed with Student's $t$-test. A $P$-value of $<0.05$ was considered as statistically significant. Data were expressed as means \pm S.D.

Acknowledgements. We thank Dr. Ahn NG for supplying the MEK constructs. We thank Dr. Penny E. Lovat for her thoughtful opinions on this study. We thank Kelly Martin and all the members of the Cellular and Molecular Biology Section for their support. We are grateful for the editorial assistance from the $\mathrm{NCl}$ Fellow Editorial Board. This research was supported by the Intramural Research Program of the NIH, Center for Cancer Research, National Cancer Institute.

1. Brodeur GM, Pritchard J, Berthold F, Carlsen NL, Castel V, Castelberry RP et al. (1993) Revisions of the international criteria for neuroblastoma diagnosis, staging, and response to treatment. J Clin Oncol 11: 1466-1477.

2. Nakagawara A, Arima-Nakagawara M, Scavarda NJ, Azar CG, Cantor AB, Brodeur GM (1993) Association between high levels of expression of the TRK gene and favorable outcome in human neuroblastoma. N Engl J Med 328: 847-854.

3. Brodeur GM, Maris JM, Yamashiro DJ, Hogarty MD, White PS (1997) Biology and genetics of human neuroblastomas. J Pediatr Hematol Oncol 19: 93-101.

4. Nakagawara A, Azar CG, Scavarda NJ, Brodeur GM (1994) Expression and function of TRK-B and BDNF in human neuroblastomas. Mol Cell Biol 14: 759-767.

5. Huang EJ, Reichardt LF (2003) Trk receptors: roles in neuronal signal transduction. Annu Rev Biochem 72: 609-642.

6. Scala S, Wosikowski K, Giannakakou P, Valle P, Biedler JL, Spengler BA et al. (1996) Brain-derived neurotrophic factor protects neuroblastoma cells from vinblastine toxicity. Cancer Res 56: 3737-3742.

7. Middlemas DS, Kihl BK, Zhou L, Zhu X (1999) Brain-derived neurotrophic factor promotes survival and chemoprotection of human neruoblastoma cells. J Biol Chem 274: $16451-16460$

8. Jaboin J, Kim CJ, Kaplan DR, Thiele CJ (2002) Brain-derived neurotrophic factor activation of TrkB protects neuroblastoma cells from chemotherapy-induced apoptosis via phosphatidylinositol 3'-kinase pathway. Cancer Res 62: 6756-6763.

9. Li Z, Jaboin J, Dennis PA, Thiele CJ (2005) Genetic and Pharmcologic Identification of Akt as a Mediator of Brain-Derived Neurotrophic Factor/TrkB Rsecue of Neuroblastoma Cells from Chemotherapy-Induced cell death. Cancer Res 65: 2070-2075.

10. Burgering BM, Coffer PJ (1995) Protein kinase B(c-Akt) in phosphatidylinositol-3-OH kinase signal transduction. Nature 376: 599-602.

11. del Peso L, Gonzalez-Garcia M, Page C, Herrera R, Nunez G (1997) Interleukin-3-induced phosphorylation of BAD through the protein kinase Akt. Science 278: 687-689.

12. Cardone MH, Roy N, Stennicke HR, Salvesen GS, Franke TF, Stanbridge E et al. (1998) Regulation of cell death protease caspase-9 by phosphorylation. Science 282: 1318-1321.

13. Ogg S, Paradis S, Gottlieb S, Patterson GI, Lee L, Tissenbaum HA et al. (1997) The Fork head transcription factor DAF-16 transduces insulin-like metabolic and longevity signals in C. elegans. Nature 389: 994-999.

14. Kops GJ, de Ruiter ND, De Vries-Smits AM, Powell DR, Bos JL, Burgering BM (1999) Direct control of the frokhead transcription factor AFX by protein kinase B. Nature 398: $630-634$.

15. Brunet A, Bonni A, Zigmond MJ, Lin MZ, Juo P, Hu LS et al. (1999) Akt promotes cell survival by phosphorylating and inhibiting a Forkhead transcription factor. Cell 96: $857-868$

16. Zheng WH, Kar S, Quirion R (2000) Insulin-like growth factor-1-induced phosphorylation of the forkhead family transcription factor FKHRL1 is mediated by Akt kinase in PC12 cells. J Biol Chem 275: 39152-39158.

17. Shin I, Bakin AV, Rodeck U, Brunet A, Arteaga CL (2001) Transforming growth factor beta enhances epithelial cell survival via Akt-dependent regulation of FKHRL1. Mol Biol Cell 12: 3328-3339.

18. Kashii Y, Uchida M, Kirito K, Tanaka M, Nishijima K, Toshima M et al. (2000) A member of Forkhead family transcription factor, FKHRL1, is one of the downstream molecules of 
phosphatidylinositol 3-kinase-Akt activation pathway in erythropoietin signal transduction. Blood 96: 941-949.

19. Abid MR, Guo S, Minami T, Spokes KC, Ueki K, Skurk C et al. (2004) Vascular endothelia growth factor activates PI3K/Akt/forkhead signaling in endothelial cells. Arterioscler Thromb Vasc Biol 24: 294-300.

20. Siegel RM, Chan FK, Chun HJ, Lenardo MJ (2000) The multifaceted role of Fas signaling in immune cell homeostasis and autoimmunity. Nat Immunol 1: 469-474.

21. Dijkers PF, Medema RH, Lammers JW, Koenderman L, Coffer PJ (2000) Expression of the pro-apoptotic Bcl-2 family member Bim is regulated by the forkhead transcription factor FKHR-L1. Curr Biol 10: 1201-1204.

22. Bouillet $P$, Zhang LC, Huang DC, Webb GC, Bottema CD, Shore P et al. (2001) Gene structure alternative splicing, and chromosomal localization of pro-apoptotic Bcl-2 relative Bim. Mamm Genome 12: 163-168.

23. Dijkers PF, Birkenkamp KU, Lam EW, Thomas NS, Lammers JW, Koenderman L et al. (2002) FKHRL1 can act as a critical effector of cell death induced by cytokine withdrawal: protein kinase B-enhanced cell survival through maintenance of mitochondrial integrity. J Cell Biol 156: 531-542.

24. Tan TT, Degenhardt K, Nelson DA, Beaudoin B, Nieves-Neira W, Bouillet $P$ et al. (2005) Key roles of Bim-driven apoptosis in epithelial tumors and rational chemotherapy. Cancer Cell 7: 227-238.

25. Egle A, Harris AW, Bouillet $P$, Cory $S$ (2004) Bim is a suppressor of Myc-induced mouse $B$ cell leukemia. Proc Natl Acad Sci USA 101: 6164-6169.

26. Gilley J, Coffer PJ, Ham J (2003) FOXO transcription factors directly activate bim gene expression and promote apoptosis in sympathetic neurons. J Cell Biol 162: 613-622.

27. Shinjyo T, Kuribara R, Inukai T, Hosoi H, Kinoshita T, Miyajima A et al. (2001) Downregulation of Bim, a proapoptotic Relative of Bcl-2, Is a Pivotal Step in Cytokine-Initiated Survival Signaling in Murine Hematopoietic Progenitors. Mol Cellular Bio 21: 854-864.

28. Weston CR, Balmanno K, Chalmers C, Hadfield K, Molton SA, Ley R et al. (2003) Activation of ERK $1 / 2$ by deltaRaf- $1: E R^{*}$ represses Bim expression independently of the JNK or PI3K pathways. Oncogene 22: 1281-1293.

29. Harris CA, Johnson Jr EM (2001) BH3-only Bcl-2 family members are coordinately regulated by the JNK pathway and require Bax to induce apoptosis in neurons. $J$ Biol Chem 276: $37754-37760$

30. Harris C, Maroney AC, Johnson Jr EM (2002) Identification of JNK-dependent and -independent components of cerebellar granule neuron apoptosis. J Neurochem $\mathbf{8 3}$ 992-1001.

31. Sugatani T, Hruska KA (2005) Akt1/Akt2 and mammalian target of rapamycin/Bim play critical roles in osteoclast differentiation and survival, respectively, while Akt is dispensable for cell survival in isolated osteoclast precursors. $J$ Biol Chem 280: $3583-3589$
32. Graos M, Almeida AD, Chatterjee S (2005) Growth factor-dependent phosphorylation of Bim in mitosis. Biochemical J 388: 185-194.

33. Harada H, Quearry B, Ruiz-Vela A, Korsmeyer SJ (2004) Survival factor-induced extracellular signal-regulated kinase phosphorylates Bim, inhibiting its association with BAX and proapoptotic activity. PNAS 101: 15313-15317.

34. Urbich C, Knau A, Fichtlscherer S, Walter DH, Bruhl T, Potente M et al (2005) FOXOdependent expression of the proapoptotic protein Bim: pivotal role for apoptosis signaling in endothelial progenitor cells. FASEB 19: 974-976.

35. Li R, Moudgil T, Ross HJ, Hu HM (2005) Apoptosis of non-small-cell lung cancer cell lines after paclitaxel treatment involves the BH3-only proapoptotic protein Bim. Cell Death Differ 12: $292-303$

36. Sunters A, Fernandez de Mattos S, Stahl M, Brosens JJ, Zoumpoulidou G, Saunders CA et al. (2003) FoxO3a transcriptional regulation of Bim controls apoptosis in paclitaxeltreated breast cancer cell lines. J Biol Chem 278: 49795-49805.

37. Puthalakath $\mathrm{H}$, Huang DC (1999) The proapoptotic activity of the Bcl-2 family member Bim is regulated by interaction with the dynein motor complex. Mol Cell 3: 287-296.

38. O'Reilly LA, Cullen L, Visvader J, Lindeman GJ, Print C, Bath ML et al. (2000) The proapoptotic $\mathrm{BH} 3$-only protein bim is expressed in hematopoietic, epithelial, neuronal, and germ cells. Am J Pathol 157: 449-461.

39. Datta SR, Brunet A, Greenberg ME (1999) Cellular survival: a play in three Akts. Genes Dev 13: 2905-2927.

40. Zhu W, Bijur GN, Styles NA, Li X (2004) Regulation of FOXO3a by brain-derived neurotrophic factor in differentiated human SH-SY5Y neuroblastoma cells. Brain Res Mol Brain Res 126: 45-56.

41. Biswas SC, Greene LA (2002) Nerve growth factor (NGF) down-regulates the Bcl-2 homology $3(\mathrm{BH} 3)$ domain-only protein Bim and suppresses its proapoptotic activity by phosphorylation. J Biol Chem 277: 49511-49516.

42. Lavoie JF, Lesauteur L, Kohn J, Wong J, Furtoss O, Thiele CJ et al. (2005) TrkA induces apoptosis of neuroblastoma cells and does so via p53-dependent mechanism. J Biol Chem 280: 29199-29207.

43. Finnberg N, El-Deiry WS (2005) Paclitaxel and velcade: the rationale for a combo. Cance Biol Ther 4: 631-634.

44. Adjei AA, Hidalgo M (2005) Intracellular signal transduction pathway proteins as targets for cancer therapy. J Clin Oncol 23: 5386-5403.

45. Kim CJ, Matsuo T, Lee KH, Thiele CJ (1999) Up-regulation of insulin-like growth factor-II expression is a feature of TrkA but not TrkB activation in SH-SY5Y neuroblastoma cells. Am J Pathol 155: 1661-1670.

46. Bokemeyer D, Sorokin A, Yan M, Ahn NG, Templeton DJ, Dunn MJ (1996) Induction of mitogen-activated protein kinase phosphatase 1 by the stress-activated protein kinase signaling pathway but not by extracellular signal-regulated kinase in fibroblasts. $J$ Biol Chem 271: 639-642. 